\title{
REGIONAL IMPACTS OF THE CONSERVATION RESERVE PROGRAM IN THE SOUTHEAST WITH CONVERSION TO TREES: AN APPLICATION OF INPUT-OUTPUT ANALYSIS
}

\author{
David Broomhall and Thomas G. Johnson*
}

\section{Introduction}

Since the late 1970's many regions in the U.S. have endured economic hardship caused by factors related to problems in agriculture. In the early 1980's high interest rates and decreasing farm prices resulted in expenses increasing relative to income for many farmers who had recently invested in new land or machinery. The strong dollar of the early to mid-eighties caused a sharp decline in the export demand for U.S. agricultural products, thereby reducing farm prices. Persistent excess production depressed prices further, causing farm incomes to decline to their lowest real level since the Great Depression. In addition, federal subsidies to agriculture, which were increasing throughout the 1980 's, were exacerbating the federal government's attempt to reduce the deficit.

At the same time there was heightened concern for soil conservation and the environmental damage that agricultural runoff was causing to rivers and streams and other water bodies. The Conservation Reserve Program (CRP) was designed to both conserve soil and increase farm income. Soil erosion would be reduced by a reduction in the intensity of land use. Farm income would be increased by reducing the number of acres in production, which would decrease the supply of agricultural commodities, thus raising prices and farm income. While the CRP has been justified on these two goals alone, it is nevertheless important that local decision-makers understand the impact of the program on their local economies.

The CRP can also have a significant impact on rural communities. A decline in farm acreage causes a decline in spending for agricultural inputs and may cause a decline in consumer spending due to reduced farm profits. Communities in primarily agricultural areas are especially vulnerable to CRP-induced reductions in economic activity. The purpose of this paper is to address the impact of the CRP on the local economy of a region dependent upon agriculture. The analysis emphasizes the impact of the CRP in a region that is being converted almost exclusively to trees. A regional input-output model is employed to evaluate these impacts.

-Graduate Research Assistant and Associate Professor, Department of Agricultural Economics, Virginia Polytechnic Institute and State University. The authors would like to thank Paul B. Siegel and two anonymous referees for their helpful comments.

\section{The Conservation Reserve Program}

The CRP was enacted by Congress in the Food Security Act of 1985 and authorized the conversion of up to 45 million acres of highly erodible cropland to soilconserving uses, such as grass and trees, for a period of at least ten years. The farmer is prohibited from using the vegetative cover for any commercial purpose (except in drought or similar emergency). In exchange the farmer is entitled to receive fifty percent of the one-time cost of establishing the permanent vegetative cover and annual rental payments for ten years.

The amount of compensation, in the form of rental payments, is determined through a bid procedure. The annual rental payment to an individual may not exceed $\$ 50,000$, and is independent of any payments that may be made under any other federal assistance programs. No more than 25 percent of an individual county's total cropland may be enrolled in the CRP without USDA approval. The acceptance of a particular bid may be based on the productivity of the land to be diverted, the potential reduction in soil erosion, and the perceived degree of economic stress.

Various studies have been conducted using inputoutput analysis to evaluate the impact of U.S. agricultural policy on state or regional economies. Mortenson et. al (1989) evaluated the impact of the CRP on the State of North Dakota, and five subregions of the state. Total income as a result of the policy was estimated to decline by .54 percent for the state, and by .91 percent for the most heavily impacted subregion.

Martin et. al (1988) evaluated the impact of the CRP on three agriculturally dependent counties in Oregon. Estimated impacts of the CRP were found to be an increase in total income of $\$ 1.25$ million in one county, a decline of $\$ 1.29$ million in the second, and a decline of $\$ 3.55$ million in the third. The impact of the CRP on the third county was more negative because the land retired into the program was more productive than the land in the other areas, and because the county serves as a subregional supply center for marketing services and agricultural inputs. The magnitude of the impacts were found to be sensitive to the migration rate of farm households that receive CRP rental payments. Neither of these studies adequately dealt with the impacts of post-retirement land use on the local economy. This study addresses this concern by tracing the impacts of the CRP on the regional economy in various stages. 


\section{Description of Study Area}

The study area chosen is a contiguous eight-county region in east central Georgia-Candler, Emanuel, Johnson, Laurens, Montgomery, Toombs, Treutlin, and Wheeler counties (Figure 1). This region covers 3,174 square miles $(2,031,000$ acres) and had an estimated 1986 population of 118,600 . This region was chosen because participation in the CRP is high, productive tendencies of the individual counties are similar ${ }^{1}$, and approximately $95 \%$ of the acreage placed in reserve is being planted in trees (USDA-ERS, 1989). Total acreage enrolled in the region through 1989 was 151,472 acres (USDA-ERS, 1989).

Agricultural production provides two direct impacts on the local economy; the purchase of farm inputs such as machinery, fertilizer, and labor, and local consumption expenditures resulting from farm profits. Table 1 presents the estimated total expenditures for farm inputs for CRP land in the region.

These estimates are based upon crop enterprise cost analyses for South Georgia for $1989 .{ }^{2}$ Estimates for sorghum were based upon 1988 estimates because more recent estimates were not available. Barley acres were combined with inputs for wheat since cost estimates for barley production were unavailable, and barley inputs are similar to inputs used for wheat production. ${ }^{3}$ Actual barley acres enrolled represented less than .4\% of total enrollment (USDA-ERS, 1989). Acres enrolled in the CRP that were already in trees or grass, or were idle totaled 8,041 acres (USDA-ERS, 1989). According to the local extension agent CRP land not used for production of program crops was almost exclusively in soybean production. For this research it is assumed that all such land was used for soybean production.

Returns to crop production were calculated based upon USDA yield estimates of the acres actually enrolled in the program. Prices used were five-year average prices for Georgia for the period 1982 to 1986, converted into 1982 dollars. Estimates of returns to agriculture are shown in Table 2.

Acomparison of yields for the majorcrops-soybeans, wheat, and corn-for the period 1982 to 1986 shows that average yields in the region averaged 18,18 , and 30 percent

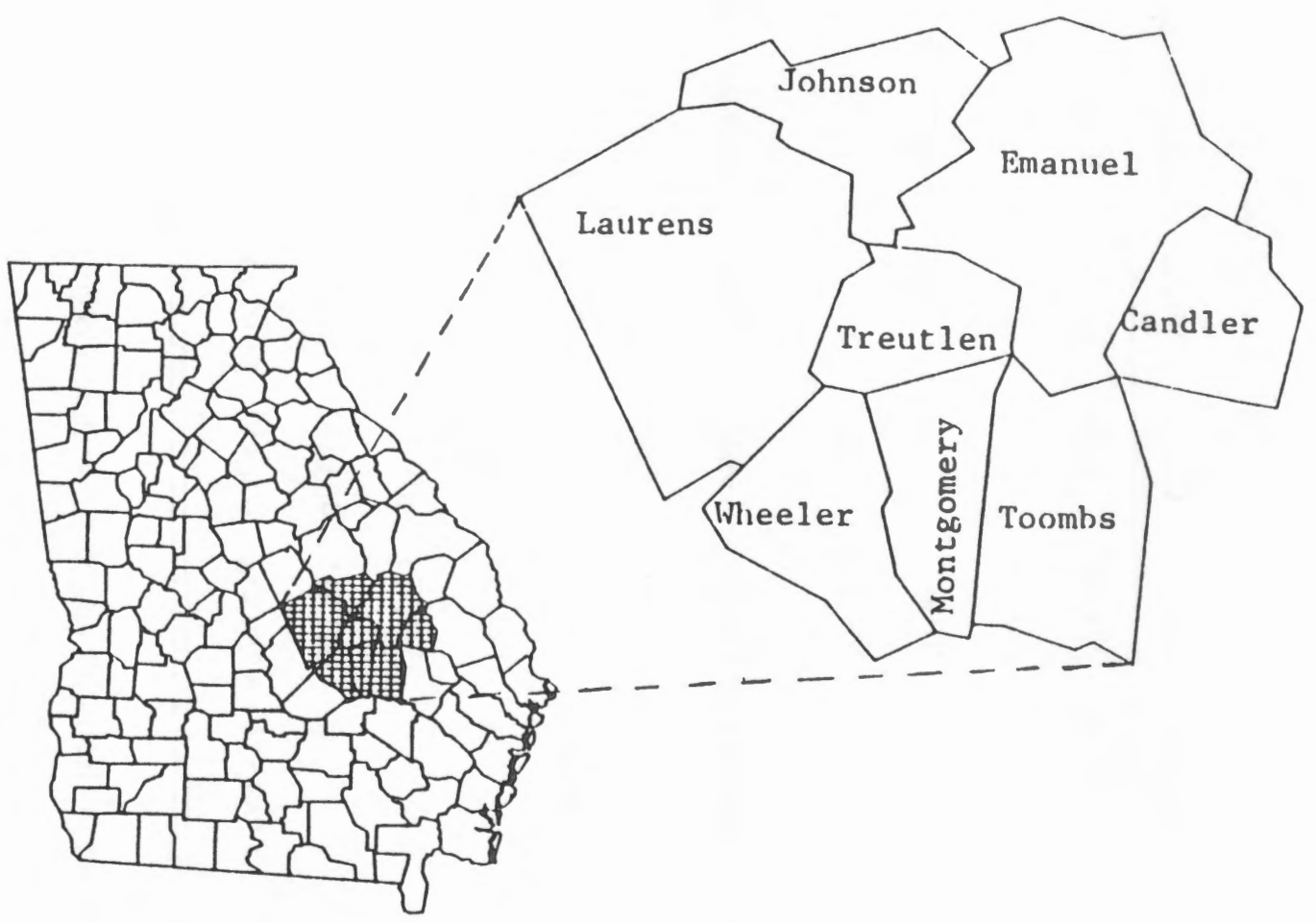

Figure 1. State of Georgia 


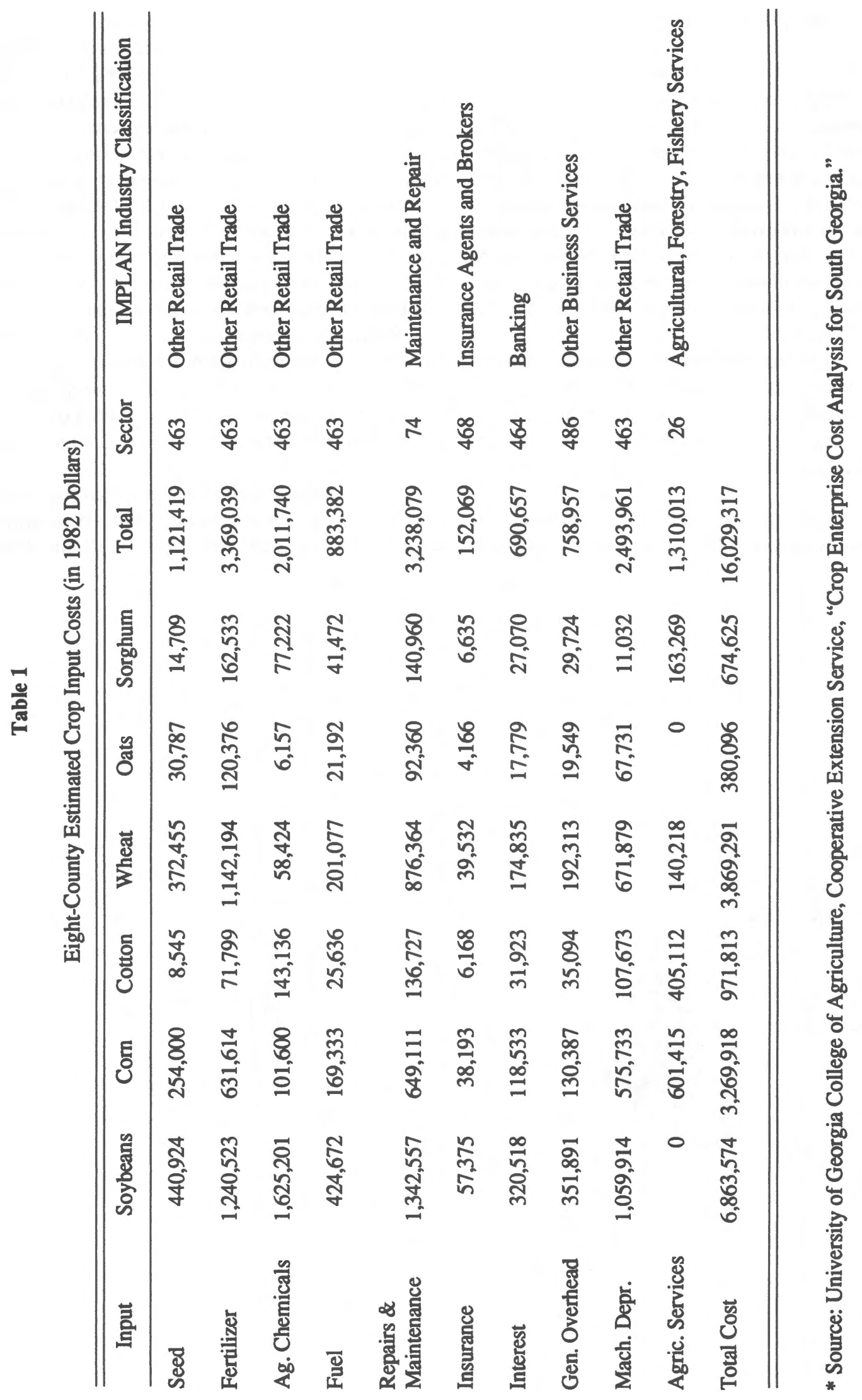


below the state average, respectively. ${ }^{4}$ The average yield on CRP land for soybeans and com was even lower than the regional average by 15 and 16 percent, respectively, while wheat yields on CRP land were 22 percent higher than the regional average.

\section{The Input-Output Model}

Input-output (I/O) models use data expressing the relationship that a particular industry has with all other industries in an economy. The model is defined by a series of relationships, or technical coefficients, which link the output of an industry to the required inputs from all other industries in the economy. The impact of a change in one or more industries on all other industries and on the entire regional economy can be examined using this method.

Various input-output models have been constructed for use in states and regions of the United States. However, since I/O models require the collection of a great deal of data, the cost of constructing a model for even a small region is quite high. The U.S. Forest Service has developed a system called IMPLAN, which has been used in recent years to construct regional $\mathrm{I} / \mathrm{O}$ models, and that have provided results consistent with those from models based on primary data (Radtke, Detering, and Brokken, 1985). IMPLAN includes a database with estimates of final demand, total output, and employment for 528 sectors, and a matrix of technical coefficients at the national level (Sieverts, et al., 1983). The IMPLAN system is very inexpensive to use when compared to models using primary data. In this analysis a regional $1 / 0$ model based on IMPLAN was constructed for the eight-county region in eastern Georgia to evaluate the impact of the CRP on total economic output and total employment in the region.
There are several assumptions used in I/O analysis that should be discussed. First, the model assumes that the relationship between factor inputsand outputs inall industries is linear (i.e. constant returns to scale). This is particularly important when the magnitude of change in an industry is large, which would likely cause a change in the existing structure of the industry, and change the technical coefficients. It is also assumed that there are no capacity constraints or excess capacity in the economy. Finally, the I/O model assumes constant technology and constant consumer preferences.

The IMPLAN system provides data on the "average" technical relationships of production for the United States. In this analysis it is known that the relationship between factor costs and total output are different than the national average, because yields on the land withdrawn from production are lower than the national average. Equation 1 shows the simple relationship between revenues and costs for the agricultural sector:

Total Revenue + Govt. Payments $=$ Total Cost + Profit

Government payments reflect the portion of income farmers receive from various commodity support programs. When a farmer enrolls land in the CRP there is necessarily a decline in government support payments and total revenue. These payments were estimated to be about $\$ 1.8$ million per year. ${ }^{5}$ But instead of introducing a change in the left-hand-side variables, the change was defined as a change in total cost (expenditures for farm inputs) and profit. Total costs were disaggregated into the appropriate input sectors, and these sectors received the direct impact of any change in expenditures. Because IMPLAN does not have a sector for each of the inputs used in production (as shown in Table

Table 2

Total Revenues per Year Generated From Crop Production (in 1982 Dollars)

\begin{tabular}{llccccr}
\hline \hline Crop & Units & $\begin{array}{c}\text { Number } \\
\text { of Acres }\end{array}$ & $\begin{array}{c}\text { Average } \\
\text { Yield }\end{array}$ & $\begin{array}{c}\text { Total } \\
\text { Yield }\end{array}$ & $\begin{array}{c}\text { Average } \\
\text { Price }\end{array}$ & $\begin{array}{r}\text { Total } \\
\text { Value }\end{array}$ \\
\hline Corn & bu & 25,037 & 44.9 & $1,123,494$ & 2.63 & $2,954,789$ \\
Sorghum & bu & 5,437 & 36.4 & 197,977 & 3.74 & 740,434 \\
Oats & bu & 4,552 & 48.5 & 220,945 & 1.48 & 326,999 \\
Wheat & bu & 43,192 & 31.7 & $1,369,507$ & 2.9 & $3,971,570$ \\
Cotton & lbs & 2,527 & 447.7 & $1,131,225$ & 0.564 & 638,011 \\
Cottonseed & ton & 2,527 & 0.48 & 1,213 & 95.95 & 116,384 \\
Soybeans & bu & 62,686 & 15.3 & 959,096 & 5.58 & $5,351,755$ \\
\hline
\end{tabular}

Source: Georgia Agricultural Facts, Georgia Crop Reporting Service, and USDA, Economic Research Service. 
1) the inputs were aggregated and placed into the sector deemed most appropriate. Table 1 shows the breakdown of total cost by the sector in which the input change occurred.

Since all costs of production are included in the crop budgets, and because profits from production on CRP land is negative, it was assumed that any change in profits would constitute a change in purchases of personal consumption goods and services. Consequently, the difference between total revenue plus government payments, and total cost was defined as a change in household income. To introduce the impact of a change in household income into the model it is necessary to have information regarding consumer expenditure patterns. IMPLAN provides a breakdown of consumer expenditures by sector for three income groups; low, medium, and high (Siverts, Palmer, and Walters, 1983). This breakdown is provided because the proportion of income spent for various goods and services varies with income. Because the analysis shows that profits from crop production on CRP land are negative, the low income category appeared to be an appropriate indicator of expected consumer expenditures. ${ }^{6}$

The IMPLAN system includes 528 sectors in the U.S. model, but only 176 of these sectors are active in the regional model. The regional model was reduced to 65 sectors by aggregating sectors of similar characteristics so that the results would be more manageable. All sectors that experienced an initial change in final demand were left unaggregated if more than $2 \%$ of the total impact affected that sector. Appendix A shows a listing of the 64 sectors used in the model.

With regard to household expenditures, if the good or service is regional in nature (e.g. automobile repairs, medi- cal services), then it was directed toward the applicable sector. If the good is either not produced locally (e.g. automobiles, computers) or the good is produced primarily for export from the region, then expenditures for such goods were directed into the retail sales sector. The sectoral breakdown of consumer goods and services by percentage of expenditures is shown in Table 3.

\section{Calculation of Impacts}

The impact of the CRP was evaluated in five stages (Table 4). All impacts were adjusted by the CPI for the southern United States to reflect impacts in 1982 dollars. In Stage One total costs and profits from agricultural production on CRP land and government payments were removed from the economy. Offsetting these losses to the economy was the fixed cost of establishing the trees and the amount of the rental payments earned by farmers.' The data regarding the fixed forest establishment costs and the total amount of rental payments received was obtained from USDA records on actual CRP enrollment (USDA, 1989).

In Stage Two the fixed forest establishment costs were removed, but the estimated cost of $\$ 2.50$ per acre per year for maintaining the forest was added. ${ }^{8}$ Stage Two occurs in years two through ten. Stage Three occurs in years 11 through 20, when no rental payments are received by farmers.

In the 21st year the timber harvest begins, at which time two economic impacts occur, the infusion of revenue from the sale of pulpwood, and the cost of harvesting. Revenues from pulpwood sales are based upon the five year average pulpwood price in the region from 1984 to

Table 3

Sector Classification and Percentage of Personal Income Spent by Expenditure Destination.

\begin{tabular}{ccl}
\hline $\begin{array}{c}\text { Percent of } \\
\begin{array}{c}\text { Personal } \\
\text { Expenditures }\end{array}\end{array}$ & Sector & \multicolumn{1}{c}{ IMPLAN Sectoral Classification } \\
\hline 0.027 & 26 & Agricultural, Forestry, Fishery Services \\
0.04 & 454 & Communication, Except Radio and TV \\
0.393 & 463 & Other Retail Trade \\
0.03 & 464 & Banking \\
0.12 & 469 & Owner Occupied Dwellings \\
0.05 & 470 & Real Estate \\
0.04 & 471 & Hotels and Lodging Places \\
0.07 & 491 & Eating and Drinking Places \\
0.03 & 493 & Automobile Repair and Service \\
0.11 & 503 & Doctors and Dentists \\
0.06 & 504 & Hospitals \\
0.03 & 521 & Other State and Local Government Enterprises \\
\hline \hline
\end{tabular}


Table 4

Total Direct Regional Impact by Activity and by Stage in Thousands of 1982 Dollars.

\begin{tabular}{lccccc}
\hline \hline \multicolumn{1}{c}{$\begin{array}{c}\text { Activity } \\
\text { (year) }\end{array}$} & $\begin{array}{c}\text { Stage 1 } \\
(1)\end{array}$ & $\begin{array}{c}\text { Stage 2 } \\
(2-10)\end{array}$ & $\begin{array}{c}\text { Stage 3 } \\
(11-20)\end{array}$ & $\begin{array}{c}\text { Stage 4 } \\
(21-25)\end{array}$ & $\begin{array}{r}\text { Stage 5 } \\
(26-40)\end{array}$ \\
\hline $\begin{array}{l}\text { Reduced Crop } \\
\begin{array}{l}\text { Prod. Costs } \\
\text { Reduced Crop }\end{array}\end{array}$ & $(\$ 16,029)$ & $(\$ 16,029)$ & $(\$ 16,029)$ & $(\$ 16,029)$ & $(\$ 16,029)$ \\
$\begin{array}{l}\text { Revenues } \\
\text { Reduced Govt. }\end{array}$ & $(14,100)$ & $(14,100)$ & $(14,100)$ & $(14,100)$ & $(14,100)$ \\
$\begin{array}{l}\text { Payments } \\
\text { Foregone Profits }\end{array}$ & $(1,878)$ & $(1,878)$ & $(1,878)$ & $(1,878)$ & $(1,878)$ \\
$\begin{array}{l}\text { Rental Pmts. } \\
\text { Government Share } \\
\text { of Estab. Costs }\end{array}$ & 52 & 52 & 52 & 52 & 52 \\
Harvest Cost & 6,499 & 6,499 & 0 & 0 & 0 \\
Pulpwood Income & 992 & 0 & 0 & 0 & 0 \\
\hline \hline
\end{tabular}

Note: A summation by column is misleading due to double counting.

1988 of $\$ 15.58$ per cord in 1982 dollars (Timber Mart South). The average yield was estimated to be 49.2 cords per acre based upon average soil characteristics (Gunter, Coder, and Rivers, 1986). Harvest costs were estimated as the difference between the stumpage price and the delivered price for pulpwood in the region. Harvest costs are highly variable over space because a large portion of the harvest cost is for transport, making location of a pulpmill a critical factor. Sixty percent of harvest costs were allocated to the trucking sector and 40 percent to the agricultural, forestry, and fishery services sector.$^{10}$ It was assumed that the harvest activity would take place over a five year period.

Investment in forest resources requires a long term commitment of capital. To reflect this fact it is assumed that the owner sells the standing trees in the twentieth year and invests the proceeds from the timber sale in a 20 year annuity at a real interest rate of 3 percent per year. Such an investment provides equivalent annual payments for a twenty year period. ${ }^{11}$ Hence the post-harvest period is divided into two stages. Stage Four represents years 21 through 25 and includes both harvest costs and annual annuity income. Stage Five represents years 26 through 40 , and includes only the annual annuity income.

The I/O model assumes that the rental payments to farmers and annuity income will be spent on consumption within the region. However, it seems fair to speculate that some farmers may leave the area, in which case some of this income will not be re-spent in the region. To account for this possibility the impact of the CRP is evaluated using two scenarios: zero migration, and a ten percent rate of migration. The migration scenario was modelled by assuming that ten percent of the rental payments and annuity income is earned and re-spent by individuals outside of the eight-county region, while all other impacts remain the same.

\section{Results}

The results indicate that in Stage One withoutmigration the CRP has a net negative impact on the regional economy amounting to $\$ 16.0$ million (1982 dollars) annually, or .94 percent of total economic output (Table 5). This negative impact increases to $\$ 18.1$ million annually , or $1.06 \%$ in Stage Two. Much larger impacts occur in Stage Three when government rental payments are discontinued, at which point total economic output declines by $\$ 26.5$ million annually, or $1.55 \%$. In Stage Four the impact of harvesting the trees occurs, causing an increase in economic activity of $\$ 48.2$ million annually, or $2.82 \%$. In Stage Five, when the harvest has been completed and only annuity income remains, the impact again becomes negative, by $\$ 13.3$ million annually, or $.78 \%$. The model imposing a ten percent migration rate shows that migration has a negative impact on economic output except in Stage Four, when the increased economic activity related to the harvest of trees outweighs the negative effects of migration.

The impacts could be less severe in Stage Three if farmers decide to put CRP land back into crop production. 
Table 5

Impact of the CRP on Total Annual Regional Economic Output With and Without Migration (in Millions of 1982 Dollars)

\begin{tabular}{lcccrr}
\hline & & \multicolumn{2}{c}{ Net Change w/o } & \multicolumn{2}{c}{$\begin{array}{c}\text { Net Change with } \\
\text { Migration }\end{array}$} \\
& & Total & Total & Migration \\
Stage & Year(s) & Dollars & Percent & -16.99 & $-1.00 \%$ \\
\hline One & $(1)$ & -15.99 & $-0.94 \%$ & -19.05 & $-1.12 \%$ \\
Two & $(2-10)$ & -18.11 & $1.06 \%$ & -26.47 & $-1.55 \%$ \\
Three & $(11-20)$ & -26.53 & $-1.55 \%$ & -76.97 & $-0.85 \%$ \\
Four & $(21-25)$ & 48.15 & $2.82 \%$ & -14.51 & Percent \\
Five & $(26-40)$ & -13.31 & $-0.78 \%$ & & \\
\hline \hline
\end{tabular}

However, data show that 86 percent of the acres in the South placed into trees during the soil bank programs of the 1950's remained in trees after the government program ended (Alig et. al, 1980).

In the region studied in this analysis it is unlikely that land will be returned to intensive production after the contract period for three reasons. First, the owner would forfeit a significant amount of future income from harvesting the trees. Second, estimated cultivated acreage declined from 608,000 to 446,000 between 1981 and 1985 , a 36 percent decline, indicating that in recent years some lands was already being removed from production. Third, an evaluation of farm revenues and expenses shows that returns to farming are negative in this area. Such a return on investment cannot be sustained in the long run unless farm revenues are augmented with off-farm income.

Some households may derive non-monetary returns for their farming efforts, and offset their farm losses with off-farm income. In this case farm losses could be sustained permanently. However, those farm households which derive non-monetary benefits from farming are less likely to enroll in the CRP, as it would reduce or eliminate this source of personal benefits.

The impact of the CRP on regional employment is shown in Table 6. ${ }^{12}$ These figures are based upon employment relationships in the various sectors that existed in 1982.

The sectoral impacts differ by stages. In Stage One the agricultural and forestry services, real estate, other state and local government, and medical services industries show increases in output. Consumer services other than medical, business services, banking, insurance, govemment services, and retail trade all experience declines in economic activity as a result of the CRP. In Stage Two, when the initial planting of trees has been completed, activity in the agricultural and forestry services industry

Table 6

Impact of the CRP on Total Regional Employment

With and Without Migration

\begin{tabular}{lccccc}
\hline \hline & & \multicolumn{2}{c}{$\begin{array}{c}\text { Net Change w/o } \\
\text { Migration }\end{array}$} & \multicolumn{2}{c}{$\begin{array}{c}\text { Net Change with } \\
\text { Migration }\end{array}$} \\
Stage & Year(s) & Total & Total \\
Employment & Percent & Employment & Percent \\
\hline One & $(1)$ & -542 & $-1.46 \%$ & -570 & $-1.53 \%$ \\
Two & $(2-10)$ & -642 & $-1.73 \%$ & -668 & $-1.80 \%$ \\
Three & $(11-20)$ & -879 & $-2.36 \%$ & -877 & $-2.36 \%$ \\
Four & $(21-25)$ & 1440 & $3.87 \%$ & 1407 & $3.78 \%$ \\
Five & $(26-40)$ & -510 & $-1.37 \%$ & -542 & $-1.46 \%$ \\
\hline \hline
\end{tabular}


declines sharply, leaving real estate, local government, and several of the medical services sectors as being the only sectors showing a positive change in economic output. In Stage Three all sectors in the regional economy show declines as a result of the CRP. In Stage Four the agriculture and forest services, and trucking industry receive substantial increases in economic activity because of increased logging activity. The impact of the increased spending in this industry causes increases in all sectors except other business services, retail trade, banking, and insurance agents. In Stage Five the harvest impacts stop, and all sectors are negatively impacted except most of the consumer services sectors and state and local government.

\section{Limitations}

A limitation of standard input-output modelling is that it is unable to evaluate impacts of new forward linkages in the economy. In this study an example of a new forward linkage would be that a new industry would move into the region to take advantage of the availability of pulpwood and/or lower pulpwood prices. Such a linkage would cause the model to underestimate total regional output in Stages Four and Five.

Another limitation is that input-output models are static in nature and thus unable to account for changes in technology, individual preferences, and the structure of the regional economy. This prevents the incorporatation of any general equilibrium effects that would occur such as price changes. These effects would likely reduce these impacts significantly.

Input/output models also assume that the regional economy instantaneously adjusts to shifts in spending patterns. In this analysis it is assumed that firms in those industries that are negatively impacted can costlessly reemploy their resources in other industries. However, in reality these firms are unable to adjust immediately to these changes. Consequently, firms from outside the region will likely satisfy some of the initial increase in demand in sectors experiencing positive impacts, thus creating further leakages in the regional economy. In addition, labor displaced from agriculture and related industries may not have the skills necessary to provide employers with the type of labor required to offer these services. And farmers that enrolled in the CRP may be reluctant to change their lifestyle and become employed in some other industry.

A final consideration regards the future of agriculture in the region without the CRP. As stated earlier various factors have caused agricultural production in the region to decline. It is likely that a continuation of factors negatively impacting agriculture would cause production to decline even without the added incentive of the CRP. If this is so, then the impacts that the model projects would be less than what would occur if the CRP did not exist. Hence the model likely overstates the impacts. Conversely, if factors affecting agriculture were to shift and become positive, then the model would understate the impact of the CRP.

\section{Conclusions and Implications}

While the Conservation Reserve Program has been shown to be effective in reducing soil erosion (Dicks et. al, 1988), the study reported here and other research has shown that regional economic impacts of the CRP may be substantial. The CRP was also designed to raise farm income by stimulating supply-induced increases in crop prices. An evaluation of the impact of these price changes on farm income is necessary for a proper evaluation of the national economic impact of the CRP.

The CRP may have other implications for the regional economy as well. The shift from agriculture to forest uses may have implications for the distribution of income in the region. There may also be implications for regional economic diversification. This could be important because economic diversification has been shown to be related to income stability (Kort, 1981). Further research in these areas could provide a better understanding of these impacts.

These results may also have implications for local decision-makers. Communities may prepare for changes by providing job retraining for displaced workers and upgrade services for retired farmers and others that choose to retire because of the CRP. Communities may also consider attracting new firms to the region to offset losses in the agricultural sector and to provide employment for displaced workers. Additional infrastructure may be needed to attract new firms and to facilitate increased use of existing infrastructure when the tree harvest occurs. Finally, since forested land provides better habitat for fish and wildlife, communities may attempt to upgrade recreational services to the local population and to attract recreationists from outside the region. Future research regarding local labor markets, migration patterns, and recreation would assist communities in adjusting to CRP induced changes in economic conditions.

Whenever a partial analysis of a particular policy is conducted it is necessarily limited in scope. While this research shows that the CRP may have a significant impact upon the local community, there are various other aspects of the CRP that may have positive impacts. Given the low returns to farming in the region it may be better from the standpoint of resource allocation that these farmers cease production. The reduction in runoff into rivers and streams may increase the quality of recreational and/or commercial 
fishing both locally and downstream. And the reduction in the use of chemical pesticides and herbicides may increase the quality of drinking water and reduce the cost of purifying water for public water systems. Further research regarding these impacts would increase our understanding of this type of policy action.

\section{Appendix A}

The sixty-five sectors used in the regional model:

\begin{tabular}{|c|c|c|c|}
\hline 1 & Dairy farm products & 219 & Gum and wood products \\
\hline 2 & Poultry and eggs & 233 & Aggregated other manufacturing \\
\hline 3 & Ranch fed cattle & 332 & Farm machinery and equipment \\
\hline 4 & Range fed cattle & 355 & Aggregated electrical manufacturing \\
\hline 5 & Cattle feedlots & 446 & Aggregated transportation, other \\
\hline 7 & Hogs, pigs, and swine & 448 & Motor freight transport \\
\hline 8 & Other meat animal products & 454 & Communications, except radio and TV \\
\hline 9 & Miscellaneous livestock & 455 & Radio and TV broadcasting \\
\hline 10 & Cotton & 457 & Aggregated other consumer services \\
\hline 11 & Food grains & 459 & Aggregated miscellaneous business services \\
\hline 12 & Feed grains & 463 & Other retail trade \\
\hline 13 & Hay and pasture & 464 & Banking \\
\hline 14 & Grass seeds & 465 & Credit agencies \\
\hline 15 & Tobacco & 467 & Insurance carriers \\
\hline 16 & Fruits & 468 & Insurance agents and brokers \\
\hline 17 & Tree fruits & 469 & Owner-occupied dwellings \\
\hline 18 & Vegetables & 470 & Real estate \\
\hline 20 & Miscellaneous crops & 471 & Aggregated personal services, other \\
\hline 21 & Oil bearing crops & 482 & Management and consulting services \\
\hline 22 & Forest products & 486 & Other business services \\
\hline 23 & Greenhouse and nursery plants & 488 & Aggregated professional services, other \\
\hline 26 & Agricultural, forestry, and fishery services & 491 & Eating and drinking places \\
\hline 27 & Landscape and horticultural services & 493 & Automobile repair and service \\
\hline 48 & Aggregated construction & 503 & Doctors and dentists \\
\hline 73 & Maintenance and repair, n.e.c. & 504 & Hospitals \\
\hline 74 & Maintenance and repair, other & 507 & Aggregated education \\
\hline 82 & Aggregated food processing & 510 & Aggregated community and social organizations \\
\hline 131 & Aggregated clothing and textiles & 516 & Aggregated other government \\
\hline 160 & Aggregated wood and paper & 521 & Other state and local government \\
\hline 178 & Aggregated metal manufacturing & 526 & Rest of the world \\
\hline 200 & Aggregated printing & 527 & Household industry \\
\hline 217 & Fertilizers, mixing only & 528 & Inventory valuation adjustment \\
\hline
\end{tabular}




\section{Notes}

${ }^{1}$ Based upon a conversation with the local extension agent.

${ }^{2}$ According to the Regional Extension Agent crop input costs in the eight-county region are approximately one-third less than in the South Georgia area. As a result, seed, fertilizer, herbicide, and machinery expenses were reduced $40 \%$, interest expenses by $30 \%$, and overhead costs by $46 \%$. Agricultural services purchased were adjusted downward by $15 \%$ to reflect local conditions.

${ }^{3}$ According to the local extension agent.

The relatively poor showing of com yields is reflective of the absence of irrigation in the region.

'This figure was calculated from State level data because data from the county level, or from actual enrollment, were unavailable.

'This assumes that off-farm income is not so large as to raise household income into the medium or high category.

The forest establishment costs were averaged for the fouryear sign-up period.

'This estimate provided by the local extension forest economist.

The primary use of plantation timber in the region is for pulpwood. In addition, unlike saw timber, trees used for pulpwood are not thinned prior to harvest.

${ }^{10}$ According to the local extension forest economist transport costs in the region are approximately 35 to 50 percent of the total harvest cost.

"Landowners that reinvest in trees must wait another 20 years before any return is realized. At that time the current annuity will expire and a new one can be purchased.

12The employment data regarding migration were not adjusted to account for the migration of the displaced CRP participants.

\section{References}

Alig, Ralph J., Thomas J. Mills, and Robert L. Shackelford. "Most Soil Bank Planting in the South Have Been Retained: Some Need Follow-Up Treatment." Southern Joumal of Applied Forestry, Vol 4, No 1, Feb. 1980, pp 60-64.

Dicks, Michael, Felix Llacuna, and Michael Linsenbigler. "The Conservation Reserve Program: Implementations and Accomplishments, 1986-87." USDA, Economic Research Service, Statistical Bulletin No. 763, 1988.

Gunter, John E., Kim D. Coder, and Walker Rivers, "Tree Planting in Georgia Under the Conservation Reserve Program.", Cooperative Extension Service, Univ of Georgia, Feb. 1986.

Kort, John, "Regional Economic Instability and Industrial Diversity." Land Economics, Nov. 1981, 57(4): 596-608.

Martin, Michael, Hans Radtke, Bart Eleveld, and S. Diane Nofziger, "The Impacts of the Conservation Reserve Program on Rural Communities: The Case of Three Oregon Counties.", Westem Journal of Agricultural Economics, December, 1988, 13(2): 225-232.

Mortenson, Timothy L., Randal C. Coon, F. Larry Leistritz, Jay A. Leitch, and Brenda L. Ekstrom, "Regional Economic Impact of the Conservation Reserve Program: An Application of Input-Output Analysis.", North Dakota Agricultural Experiment Station, January, 1989.

Radtke, Hans, Stan Detering, and Ray Brokken, "A Comparison of Economic Estimates for Changes in the Federal Grazing Fee: Secondary vs. Primary Data I/O Models.", Westem Journal of Ag. Economics, December, 1985, 10(2):382-390.

Siverts, E., C. Palmer, and K. Walters. "IMPLAN User's Guide." Fort Collins, CO. US Forest Service, Sept. 1983.

Timber Mart South, Inc. Highlands, NC, various issues, 1984-88. United States Department of Agriculture, Economic Research Service, data and statistics regarding CRP enrollment and participation, 1989. 